\title{
Structural changes associated with drought stress symptoms in foliage of Central European oaks
}

\author{
Pierre Vollenweider $^{1} \cdot$ Terry Menard $^{1} \cdot$ Matthias Arend $^{1} \cdot$ Thomas M. Kuster $^{2}$. \\ Madeleine S. Günthardt-Goerg ${ }^{1}$
}

Received: 29 July 2015/Revised: 11 November 2015/Accepted: 14 November 2015/Published online: 10 December 2015 (C) Springer-Verlag Berlin Heidelberg 2015

\begin{abstract}
Key message In droughted oak foliage, water shortage and carbon starvation caused structural injury varying in severity between cell types and indicative of adaptive reversible and degenerative irreversible processes.

Abstract Warmer temperatures as a consequence of climate change have already started to affect forest ecosystems, enhancing drought frequency and severity. Also depending on drought chronicity and ontological tissue development, tree foliage can respond to drought by enhancing structural acclimation and thus delay injury. More comprehensive characterization of micromorphological responses in foliage is needed for evaluating the tolerance of forest trees in the future. In the present study, structural reactions in foliage of three oak species exposed to acute summer drought were analyzed using transmitted light, fluorescence and electron microscopy. Oak leaves withstood drought stress for a considerable length of time before injury in the form of necrotic leaf margins appeared. In the leaf parts still asymptomatic, structural changes indicative of water stress and carbon starvation were observed. In the epidermis, autophagic processes-with exocytosis of degraded material—contributed to cell wall thickening. However, they also accelerated the degeneration of cell content whereas stomatal guard cells often remained unscathed. In mesophyll, the material in autolytic
\end{abstract}

Communicated by K. Masaka.

Pierre Vollenweider

vollenwe@wsl.ch

1 Swiss Federal Research Institute for Forest, Snow and Landscape Research WSL, 8903 Birmensdorf, Switzerland

2 Agroscope, 8820 Wädenswil, Switzerland vesicles was internalized in vacuoles, which contributed to maintaining the cell turgescence. Plugging of xylem and phloem cells with polysaccharidic and proteinic material was mechanistically related to necrosis of leaf margins. These structural changes were indicative of reversible adaptive and irreversible degenerative processes. The functionality of upper mesophyll and stomata was prioritized, allowing foliage to resume gas exchange within hours of rewatering. Hence, extensive structural changes within still asymptomatic parts of the foliage were accountable in increasing the drought tolerance of the oaks.

Keywords Acute summer drought - Central European oaks - Leaf anatomy - Ultrastructure - Water and carbon starvation $\cdot$ Drought tolerance

\section{Introduction}

Global aridity has been substantially increased since the 1970s, as a consequence of drying affecting various world regions (Dai 2011; IPCC 2014). Irrespective of the future climate scenario, soil moisture availability is expected to decrease worldwide and the frequency of short- and longterm droughts to be doubled and tripled until the end of twenty-first century (Sheffield and Wood E 2008). On a regional scale, Central Europe has experienced an enhanced risk of drought recently which is expected to further increase through synergies between reduction in precipitation, lower soil moisture and higher evapotranspiration (Bey et al. 2011). Higher surface temperatures have already caused phenological changes and shifts of species habitat (CH2014-Impacts 2014; Defila and Clot 2001; Rigling et al. 2013). Together with more frequent droughts, they form an indirect cause regarding recent 
increases in tree mortality in, e.g., the dry pine stands at low elevation within some inner valleys in the Alps (Allen et al. 2010; Rebetez and Dobbertin 2004). In the future, other Central European forests at low elevation should also be affected and the increase of drought stress may pose a major threat regarding their stability (Allen et al. 2010; CH2014-Impacts 2014).

In a warmer climate, the responses of forest trees to changing environmental constraints will depend on limitation to growth by present temperature, simultaneous changes in precipitation and interactions with additional abiotic and biotic stress factors (CH2014-Impacts 2014; Saxe et al. 2001). Within trees suffering from drought, leaves and needles are the organs experiencing the lowest water potential and showing some of the worst injuries (Bréda et al. 2006; Cruiziat et al. 2002). Given their dependency on site conditions, trees as well as all other vascular plants react and/or adapt to shifting environmental conditions by means of structural changes at cell, tissue and organ level (Abrams and Kubiske 1990; Fink 1999; Günthardt-Goerg and Vollenweider 2007). Not only can each stress factor trigger a range of characteristic structural modifications, but also the interaction with other constraints will determine the symptom micromorphology and severity (Paoletti et al. 2009; Vollenweider et al. 2013). In the case of drought stress, the structural responses, thus, vary as a function of the drought severity, chronicity and ontological tissue development. Leaves affected by water stress during their ontological development show fewer and smaller organelles in mesophyll or increased lignification within veinlet or hypodermis cells (Grill et al. 2004; Pitman et al. 1983). In differentiated leaves, acute water stress causes the development of gradients of injury with stress symptoms within most cell organelles and characteristic terminal stages including the disruption of compartments, plasmolysis and cytorrhisis (Olmos et al. 2007; Ristic and Cass 1991; Vassileva et al. 2012). Foliage under chronic water stress shows enhanced xeromorphic traits (Abrams 1990; Günthardt-Goerg et al. 2013; López et al. 2010; Lukovic et al. 2009). However, most reports focus on a few tissues-often the mesophyll-and, in the case of woody species, primarily on responses to chronic water stress. A more comprehensive investigation of structural acclimation and tolerance processes in reaction to acute summer drought in the foliage of forest tree species is still missing.

Within the temperate forests of northern hemisphere, oaks belong to the most drought-tolerant forest tree species. This tolerance relates to different traits including (1) a deep and versatile root system, (2) conservative growth and carbon allocation patterns, (3) diverse adaptations in the leaf morphology including increase in the leaf lamella and cuticle thickness, increasing density and decreasing size of stomata, (4) close control of gas exchanges and osmotic potential and (5) drought-resistant photosystem activities or carbon-fixing enzymes, all varying between species and ecotypes with a tendency to increased plasticity in more drought-tolerant oaks (Abrams 1990; Dickson and Tomlinson 1996; Polomski and Kuhn 1998). In the case of Central European oaks, several studies have confirmed the superior tolerance to drought of oaks vs. other forest trees and the inter- or intraspecific variability of tree responses (Leuzinger et al. 2005; Arend et al. 2013; Günthardt-Goerg et al. 2013; Kuster et al. 2013b). In the latter studies moreover, (1) the mesic Quercus robur was confirmed to be more sensitive than the more xerophilous $Q$. petrae $a$ and pubescens and (2) the drought effects were exacerbated by the elevated daytime temperature, with responses varying according to soil type. However, the structural adaptations and tolerance responses at tissue and cell level in oak foliage have not been investigated in detail so far. Regarding the adaption of low elevation forest ecosystems of Central Europe to warmer and drier climate conditions, oak species and their range of ecotypes appear promising, but their tolerance mechanisms needs further characterization.

This study was realized in the framework of the experiment "Querco", with young Q. robur, petraea, pubescens trees exposed to acute drought, mild elevated temperature and their combination on two different forest soils (Arend et al. 2013; Günthardt-Goerg et al. 2013; Kuster et al. 2013a). Whilst high levels of tolerance to repeated water shortage and low soil moisture were observed in the oaks during the first two experimental years, a more intense drought during the third year of treatment caused the development of visible leaf injury in the foliage (Günthardt-Goerg et al. 2013). This study was then launched with a view to (1) analyzing the structural changes associated with drought stress injury and (2) identifying the processes within the foliage involved in drought-stress tolerance. We focused on the visible symptoms most typical of and specific to drought stress - namely, gradients of leaf margin necrosis along shoots (Hartmann et al. 2007; Vollenweider and Günthardt-Goerg 2006)—which also formed the injury most frequently observed (GünthardtGoerg et al. 2013). Therefore, symptomatic and asymptomatic leaf material was harvested just after detecting the first visible injury and before resuming irrigation. The tissue- and cell-level changes in the leaf structure of still green parts of the leaves were investigated using several methods in transmitted light (LM), fluorescence and transmission electron microscopy (TEM). All leaf tissues were systematically investigated to comprehensively describe the structural reactions and responses and to relate them to physiological processes accountable for specific drought stress symptoms. 
Table 1 Water supply, air temperature (1.20 m above ground) and soil water concentration in the Querco experiment (mean $\pm \mathrm{SE}$; $n=4$ ) by the time of sampling for microscopy within the control
(CO), air warming (AW), drought (D) and combination (AWD) treatment (measurement date for temperature: 29.06.2009 and soil water concentration: 30.06.2009)

\begin{tabular}{|c|c|c|c|c|c|c|c|c|}
\hline \multirow{2}{*}{$\begin{array}{l}\text { Treatment } \\
\text { Soil type }\end{array}$} & \multicolumn{2}{|l|}{$\mathrm{CO}$} & \multicolumn{2}{|l|}{ AW } & \multicolumn{2}{|l|}{$\mathrm{D}$} & \multicolumn{2}{|l|}{ AWD } \\
\hline & Acidic & Calcareous & Acidic & Calcareous & Acidic & Calcareous & Acidic & Calcareous \\
\hline $\begin{array}{l}\text { Water supply }{ }^{\mathrm{a}} \\
(\mathrm{mm})\end{array}$ & 522 & & 522 & & 186 & & 186 & \\
\hline \multicolumn{9}{|c|}{ Temperature $\left({ }^{\circ} \mathrm{C}\right)$} \\
\hline $\begin{array}{l}\text { Day mean } \\
\qquad(08-18 \mathrm{~h})\end{array}$ & $27.6 \pm 0.23$ & & $28.8 \pm 0.24$ & & $29.6 \pm 1.05$ & & $31.6 \pm 0.45$ & \\
\hline $\begin{array}{l}\text { Day and night } \\
\text { mean } \\
(00-24 \mathrm{~h})\end{array}$ & $22.9 \pm 0.15$ & & $23.5 \pm 0.02$ & & $24.2 \pm 0.51$ & & $25.2 \pm 0.22$ & \\
\hline \multicolumn{9}{|c|}{ Soil water concentration $\left(\mathrm{m}^{3} / \mathrm{m}^{3}\right)$} \\
\hline $12 \mathrm{~cm}$ depth & $0.23 \pm 0.015$ & $0.19 \pm 0.013$ & $0.20 \pm 0.021$ & $0.21 \pm 0.004$ & $0.04 \pm 0.007$ & $0.03 \pm 0.004$ & $0.04 \pm 0.003$ & $0.03 \pm 0.002$ \\
\hline $88 \mathrm{~cm}$ depth & $0.16 \pm 0.025$ & $0.21 \pm 0.026$ & $0.17 \pm 0.026$ & $0.23 \pm 0.015$ & $0.06 \pm 0.008$ & $0.04 \pm 0.004$ & $0.07 \pm 0.008$ & $0.03 \pm 0.004$ \\
\hline
\end{tabular}

See Kuster et al. (2013a) for the description of methods

${ }^{a}$ Natural precipitation (01.01-09.03.2009) and controlled irrigation (10.03-29.06.2009)

\section{Materials and methods}

\section{Experimental design and plant material}

The experimental settings and treatments have been previously described in detail (Arend et al. 2013; GünthardtGoerg et al. 2013; Kuster et al. 2013a). Briefly, the Querco experiment was carried out from 2007 to 2009 in the model ecosystem facility (MODOEK) of the Swiss Federal Institute for Forest, Snow and Landscape Research WSL in Birmensdorf, Switzerland $\left(47^{\circ} 21^{\prime} 48^{\prime \prime} \mathrm{N}, 8^{\circ} 27^{\prime} 23^{\prime \prime} \mathrm{E}, 550 \mathrm{~m}\right.$ a. s. $1 ., 8.5^{\circ} \mathrm{C}$ mean annual temperature, $1100 \mathrm{~mm}$ annual rainfall). The MODOEK consists of 16 open top chambers (OTC) arranged in a Latin square, with four treatments (control: $\mathrm{CO}$, air warming: $\mathrm{AW}$, drought: $\mathrm{D}$, combination: AWD) and four repetitions of each. Each chamber has an aboveground volume of $20.1 \mathrm{~m}^{3}$ and overlays two $4.5 \mathrm{~m}^{3}$ (1.5 m deep) lysimeter compartments. For this experiment, each compartment was filled with a quartz gravel drainage layer $(50 \mathrm{~cm}$ ) and $100 \mathrm{~cm}$ forest soil, either acidic (acidic loamy sand, initial $\mathrm{pH}$ in $0.01 \mathrm{M} \mathrm{CaCl}_{2}=4.0$, originating from a Haplic Alisol along the Rhine river, Switzerland) or calcareous (calcareous sandy loam, initial $\mathrm{pH}$ in $0.01 \mathrm{M}$ $\mathrm{CaCl}_{2}=6.9$, originating from a Calcaric Fluvisol along the Aare river, Switzerland). From March to October, the ambient precipitation was excluded using the OTC's retractable glass roofs and the plots were irrigated with synthetic water $(\mathrm{pH} 5.5)$ which ionic composition was based on the last 30-year rainwater average at WSL. In the $\mathrm{D}$ and AWD treatment, the irrigation was interrupted during periods of several weeks to create drought conditions. In 2009 during spring and summer, there were two periods of suppressed irrigation amounting to 16 and 6 weeks each. During the vegetation season, the daytime air temperature in the $\mathrm{AW}$ vs. $\mathrm{CO}$ treatment was passively elevated by $1-2{ }^{\circ} \mathrm{C}$ by reducing the opening angle of the OTC's side walls (Kuster et al. 2013a). As a consequence of reduced evaporative cooling, air temperature was also enhanced by the drought treatment $\left(\geq 1.5^{\circ} \mathrm{C}\right)$ and the combined drought and air warming effects in the AWD vs. $\mathrm{CO}$ treatment thus led to air temperature increase of $3{ }^{\circ} \mathrm{C}$ in 2009.

In spring of 2006 before the start of experiment, each OTC compartment was planted with 242 -year-old saplings belonging to the three main Central European oak species (Quercus robur L., Q. petraea [Matt.]Liebl., Q. pubescens Willd.) with four provenances each and two replicate trees per provenance. Except for the $Q$. pubescens provenance from northern Italy, all seed collection sites were located in Switzerland (199-900 m a.s.l.). They were characterized by a range of mesic to xeric site conditions with annual precipitation ranging from 410 to $1772 \mathrm{~mm}$ and annual temperature from 6.1 to $14{ }^{\circ} \mathrm{C}$ (Arend et al. 2011, Günthardt-Goerg et al. 2013).

\section{Environmental conditions and physiological status of oaks by the time of sampling for microscopy}

As shown by Kuster et al. (2013a), oaks experienced contrasting environmental conditions and severe drought during the two periods of suppressed irrigation in 2009 . Until sampling for microscopy by the end of first period (30.06.2009), reduction in the water supply by $64 \%$ in the $\mathrm{D}$ and AWD vs. CO treatment had caused a decrease in the 


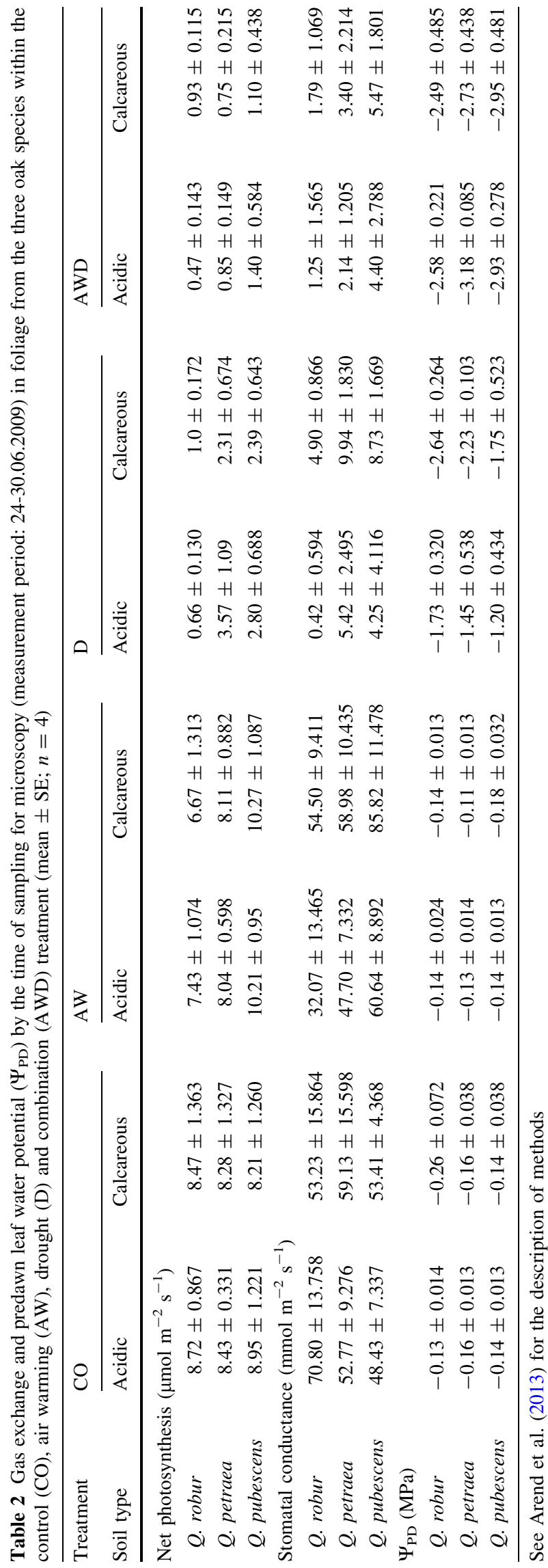

soil water concentration amounting to $57-83 \%$ in the acidic and to more than $80 \%$ in the calcareous soil (Table 1). Higher vapour pressure deficits were indicated by daytime air temperature increase up to 2 and $4{ }^{\circ} \mathrm{C}$ in the $\mathrm{D}$ and AWD treatment. With air temperature increase of $1-2{ }^{\circ} \mathrm{C}$ during the growing season, moderate air warming in the AW vs. $\mathrm{CO}$ treatment had no effect on soil water availability or evapotranspiration (Kuster et al. 2013a). Compared to the $\mathrm{D}$ treatment, additional air warming in the AWD treatment did not change the soil water availability or evapotranspiration but only lowered the pre-dawn leaf water potentials.

Arend et al. (2013) found that the imposed drought caused a sizable decrease in the gas exchange and leaf water potential of oaks. These effects were exacerbated by additional air warming in the AWD vs. D treatment. When samples were harvested for microscopy, Q. robur, petraea and pubescens in the D and AWD vs. CO treatment, they had decreased their net photosynthesis by 90,65 and $70 \%$ in the D and 92, 90 and $85 \%$ in the AWD treatment (Table 2). Their stomatal conductance had dropped by 99 , 90 and $91 \%$ in the D and 98, 96 and $91 \%$ in the AWD treatment. Severe drought stress was indicated by predawn leaf water potential ranging between -1.2 and -1.64 in the $\mathrm{D}$ and -2.49 and $-3.018 \mathrm{Mpa}$ in the AWD treatment (Table 2). With significant enhancement of net photosynthesis and no influence on the stomatal conductance and pre-dawn leaf water potentials, air warming alone, by contrast, had no detrimental effects on the leaf physiology (Arend et al. 2013).

\section{Assessment of the visible symptoms of drought stress, sampling and microscopic analysis}

In 2009, the development of visible symptoms in foliage of all oak provenances was monitored to analyze the drought injury dynamic. Specific drought stress injury was distinguished from other foliar symptoms by drought and other stress factors on the basis of the injury distribution and morphological traits (Günthardt-Goerg et al. 2013; Hartmann et al. 2007; Vollenweider and Günthardt-Goerg 2006).

Sampling for microscopic analysis was carried out after observing the first symptoms of drought stress and before resuming irrigation (30.06.2009). Selecting the same oak provenance per species as in the former physiological assessments (i.e. Q. robur Tägerwilen, $Q$. petraea Corcelles and $Q$. pubescens Leuk; Arend et al. 2013), three trees per species were sampled in the CO and AWD treatment (acidic soil). Indeed, the AW treatment did not lead to leaf injury. The drought stress symptoms in the D and AWD treatment were the same but there were more symptomatic trees in the AWD treatment (Günthardt- 

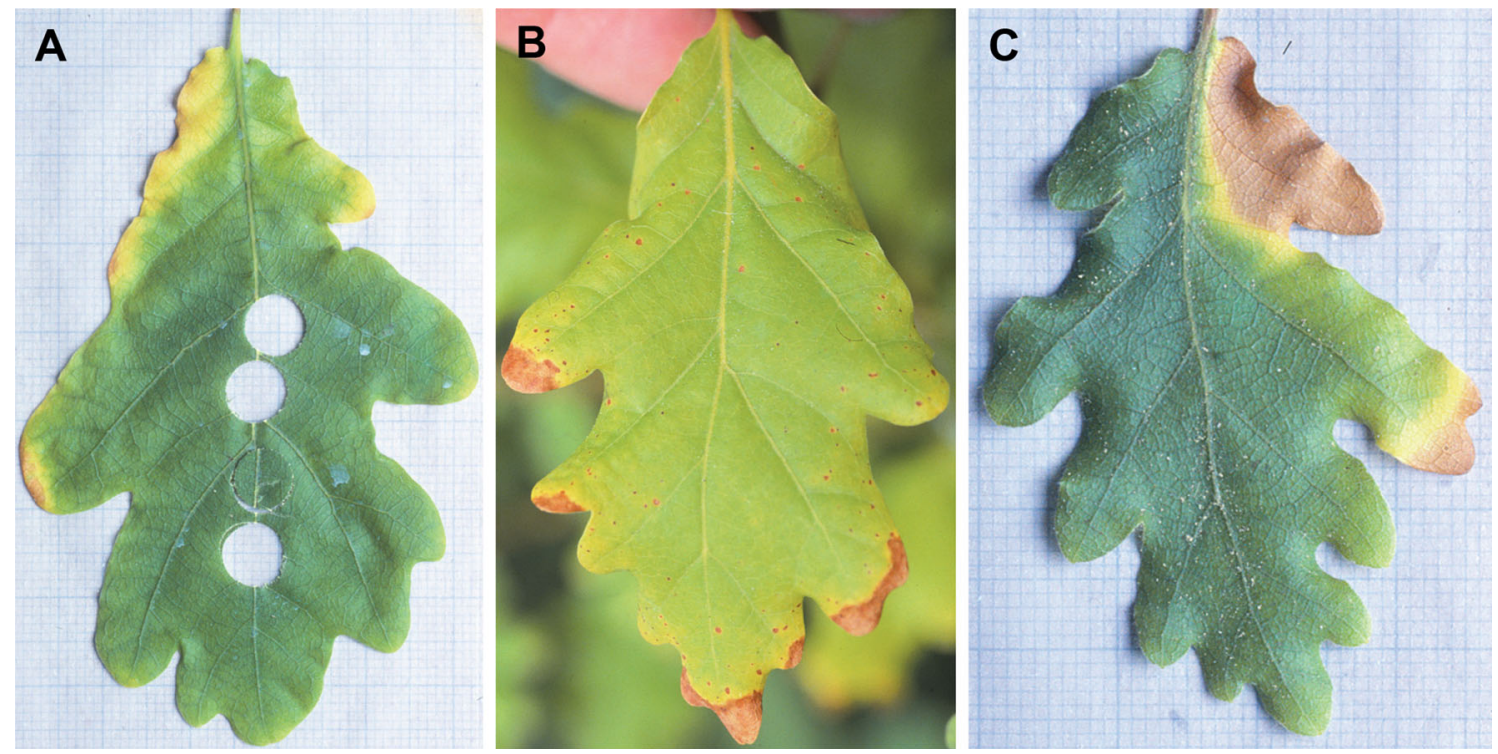

Fig. 1 Specific drought stress injury in leaves of $Q$. robur (a), $Q$. petraea (b) and $Q$. pubescens (c) by the time of sampling (30.06.2009; a, c), and before the beginning of second drought period $(08.07 .2009 ; \mathbf{b})$. At leaf level, symptoms appeared as more or

Goerg et al. 2013). Given the distribution of drought stress injury in gradients, one leaf showing specific drought stress injury at shoot basis and its first acropetal and asymptomatic neighbor were selected in the first-flush shoot of one branch at mid-crown position per tree. In $Q$. petraea and $\mathrm{CO}$ treatment, no drought stress injury was observed and only asymptomatic leaves at shoot basis were sampled ( $n=24$ samples). Disks $7 \mathrm{~mm}$ in diameter and including the leaf main vein and limb tissues (Fig. 1a) were excised from the asymptomatic middle part of leaf. They were immediately fixed, using either LM- or EM-grade $2.5 \%$ glutaraldehyde buffered at $\mathrm{pH} 7.0$ with a $0.067 \mathrm{M}$ Soerensen phosphate buffer and stored at $4{ }^{\circ} \mathrm{C}$ after full infiltration with renewed fixing solution by evacuation. For enabling maximum starch grain size within chloroplasts, sampling was carried out in the afternoon of June 30, 2009 (4-7 p.m., local time).

For analysis in light microscopy, samples were dehydrated with 2-methoxyethanol (three changes), ethanol, n-propanol, and n-butanol (Feder and O'Brien 1968) and embedded in Technovit 7100 (Kulzer HistoTechnik). Semi-thin cuttings $(2 \mu \mathrm{m})$ were sectioned using a Reichert UltraCut S ultramicrotome, stained (Table 3) and mounted in DPX. All sections were observed using a Leica microscope Leitz DM/RB, $5 \times$ to $100 \times$ objectives and either diascopic or episcopic (fluorescence) light illumination. Micrographs were taken using either the digital Leica DC 500 camera interfaced by the Leica DC500 TWAIN software under control of the Image Access Enterprise 5 (Imagic, Glattbrugg, Switzerland) image management less extended discrete necrosis along leaf margins and in lobe tips, whereas the inner part of leaf remained asymptomatic. Typical sampling position in the leaf of the $7 \mathrm{~mm}$ disks excised with a view to microscopic assessments is shown in the case of $Q$. robur (a)

system (transmitted light microscopy), or the analogous micrograph system Wild MPS 48/52 using Kodak Ektachrome 400 Asa films (fluorescence microscopy). EMgrade fixed samples were post-fixed in buffered $2 \%$ OsO4, dehydrated by a series of graded ethanol, infiltrated by a series of graded propylene oxide/Epon 812 mixture (with DDSA, NMA and DMP hardener) and embedded in Epon. Ultra-thin cuttings $(70 \mathrm{~nm})$ were sectioned using the aforementioned ultramicrotome, mounted on copper grids and contrasted using saturated uranyl acetate in $50 \%$ ethanol and lead citrate (Reynolds procedure). Sections were observed using a Philips CM 12 transmission electron microscope.

\section{Statistical analysis}

For each observation date, estimates of the foliage percentage showing specific drought stress injury within each treatment and per soil type were obtained by averaging data from two trees per oak provenance. Since the specific drought stress symptoms were never observed in the $\mathrm{CO}$ and AW treatment, only trees from the D and AWD treatment were included in the statistical analyses. Differences between sampling dates, treatments, soil types, oak species and provenances were tested by means of repeated measure ANOVA using the GLM procedure of Statistica software package (Stat Soft. Inc., Tulsa OK). Besides the measurement date (within effect factor), factors were ordered within a partly hierarchical statistical design including the independent factors air warming and species 
Table 3 Metachromatic and specific staining methods for cell wall and protoplasmic structures (stain dilution in w/v)

\begin{tabular}{|c|c|c|c|c|c|c|c|}
\hline Stain & References & Solution & $\begin{array}{l}\text { Staining time } \\
(\min )\end{array}$ & $\begin{array}{l}\text { Color in } \\
\text { transmitted } \\
\text { light }\end{array}$ & $\begin{array}{l}\text { Excitation } \\
(\mathrm{nm})\end{array}$ & $\begin{array}{l}\text { Application } \\
\text { target }\end{array}$ & Fig. \\
\hline Toluidine blue $\mathrm{O}$ & $\begin{array}{l}\text { Feder and } \\
\text { O'Brien } \\
(1968)\end{array}$ & $\begin{array}{c}0.05 \% \text { aq., acetate } \\
\text { buffer pH } 4.4\end{array}$ & 10 & Blue & - & $\begin{array}{l}\text { Metachromatic } \\
\text { stain }\end{array}$ & $\begin{array}{l}3 \mathrm{~A}, \mathrm{~B} \\
\text { 4A-D, } \\
\text { 5A, B } \\
\text { 6A-D }\end{array}$ \\
\hline $\begin{array}{l}\text { Calcofluor White } \\
\text { Mr2 }\end{array}$ & Munck (1989) & $\begin{array}{l}0.1 \% \text { in } 50 \% \text { ethanol } \\
\text { aq. }\end{array}$ & 2 & - & $340-380$ & Cellulose & $\begin{array}{l}\text { Figure not } \\
\text { shown }\end{array}$ \\
\hline Coriphosphine & $\begin{array}{l}\text { Weis et al. } \\
\quad(1988)\end{array}$ & $0.03 \%$ aq. & 2 & - & $450-490$ & Pectins & $\begin{array}{l}\text { Figure not } \\
\text { shown }\end{array}$ \\
\hline $\mathrm{PARS}^{\mathrm{c}}$ & Gahan (1981) & $\begin{array}{l}0.5 \% \text { periodic acid; } \\
\text { Schiff reagent; } 0.5 \% \\
\text { potassium } \\
\text { metabisulfite in } 0.05 \\
\mathrm{~N} \mathrm{HCl}\end{array}$ & $10 ; 20 ; 3 \times 5$ & Pink & - & Polysacharides & $3 \mathrm{C}-\mathrm{D}, 6 \mathrm{~F}$ \\
\hline Aniline blue & $\begin{array}{l}\text { Gerlach } \\
\quad(1984)\end{array}$ & $\begin{array}{l}0.005 \% \text { in Soerensen } \\
\text { buffer } \mathrm{pH} 8.2\end{array}$ & 10 & - & $340-380$ & Callose & $\begin{array}{l}\text { Figure not } \\
\text { shown }\end{array}$ \\
\hline Phloro-glucinol & $\begin{array}{l}\text { Schneider } \\
\text { (1979) as } \\
\text { cited by } \\
\text { Clark 1981, } \\
\text { modified }\end{array}$ & saturated in $18 \% \mathrm{HCl}$ & $\begin{array}{l}\text { Observed in } \\
\text { reagent }\end{array}$ & Pink & - & Lignin & $\begin{array}{l}\text { Figure not } \\
\text { shown }\end{array}$ \\
\hline \multirow[t]{2}{*}{$\begin{array}{l}\text { Coomassie brilliant } \\
\text { blue }\end{array}$} & $\begin{array}{l}\text { Wetzel et al. } \\
\text { (1989), } \\
\text { modified }\end{array}$ & $\begin{array}{l}0.025 \% \text { in } 100 \% \\
\text { ethanol : acetic acid } \\
3: 1\end{array}$ & 35 & Blue & - & Proteins & $6 \mathrm{M}, \mathrm{N}$ \\
\hline & $\begin{array}{l}\text { Brundrett et al. } \\
\quad \text { (1991) }\end{array}$ & $\begin{array}{l}0.2 \% \text { in } 100 \% \text { ethanol } \\
\quad \text { : glycerin } 1: 1\end{array}$ & $\begin{array}{l}\text { Observed in } \\
\text { reagent }\end{array}$ & Blue-black & - & Lipids & $\begin{array}{l}\text { Figure not } \\
\text { shown }\end{array}$ \\
\hline Sudan-black B & $\begin{array}{l}\text { Kivimäenpää } \\
\text { et al. (2004) }\end{array}$ & $\begin{array}{l}1 \% \text { in iso- } \\
\text { propanol:methanol } \\
1: 1\end{array}$ & 4 & Dark grey & - & Lipids & $\begin{array}{l}\text { Figure not } \\
\text { shown }\end{array}$ \\
\hline $\begin{array}{l}p \text {-Phenylenediamine } \\
\mathrm{H}_{2} \mathrm{SO}_{4} 3 \mathrm{M}\end{array}$ & $\begin{array}{r}\text { Gutmann } \\
\text { (1993) }\end{array}$ & $\mathrm{H}_{2} \mathrm{SO}_{4} 3 \mathrm{M}$ in butanol & $\begin{array}{l}450 \mathrm{~W} \\
\text { irradiation } \\
\text { cycles of } 15 \text { “ } \\
\text { in a } \\
\text { Microwave } \\
\text { oven }\end{array}$ & $\begin{array}{l}\text { Purple- } \\
\text { brown }\end{array}$ & - & $\begin{array}{l}\text { Condensed } \\
\text { tannins }\end{array}$ & $\begin{array}{l}\text { Figure not } \\
\text { shown }\end{array}$ \\
\hline
\end{tabular}

(whole plot factor) whereas the split-plot soil and provenance factor were nested within air warming and species, respectively. Violations of the compound symmetry and sphericity assumptions were remedied using GreenhouseGeisser and Huynh-Feldt univariate adjustment factors and the univariate results were further verified using the multivariate tests for repeated measure. Differences between groups were tested by means of Tukey HSD post hoc tests.

\section{Results}

\section{Specific drought stress symptoms}

Specific drought stress injury consisted of gradients of leaf margin necrosis increasing basipetally on the first flush of yearly shoots (Fig. 1). The intact veinlets and distribution of injury as gradients verified the drought stress diagnosis with regard to excluding other abiotic and biotic stress factors causing similar leaf injury (Hartmann et al. 2007; Vollenweider and Günthardt-Goerg 2006). By the end of first drought period in 2009, only a low percentage of trees had developed symptoms ( $Q$. robur/petraealpubescens $9.4 \% / 0 \% / 13.5 \%$ ) and the proportion of foliage affected, remained small (Fig. 2). During the second drought stress period in the same year, the percentage of symptomatic foliage increased sizably. Overall, higher values were recorded in the AWD vs. D treatment $(P=0.016, d f=1)$. Significant differences between species were also observed $(P<0.001, d f=2)$, with $Q$. robur and $Q$. pubescens showing more specific drought stress injury than $Q$. petraea. Differences between the $\mathrm{D}$ and $\mathrm{AWD}$ treatment became significant by the 16 th of September $(P=0.002$; last assessment) whereas those between species were 


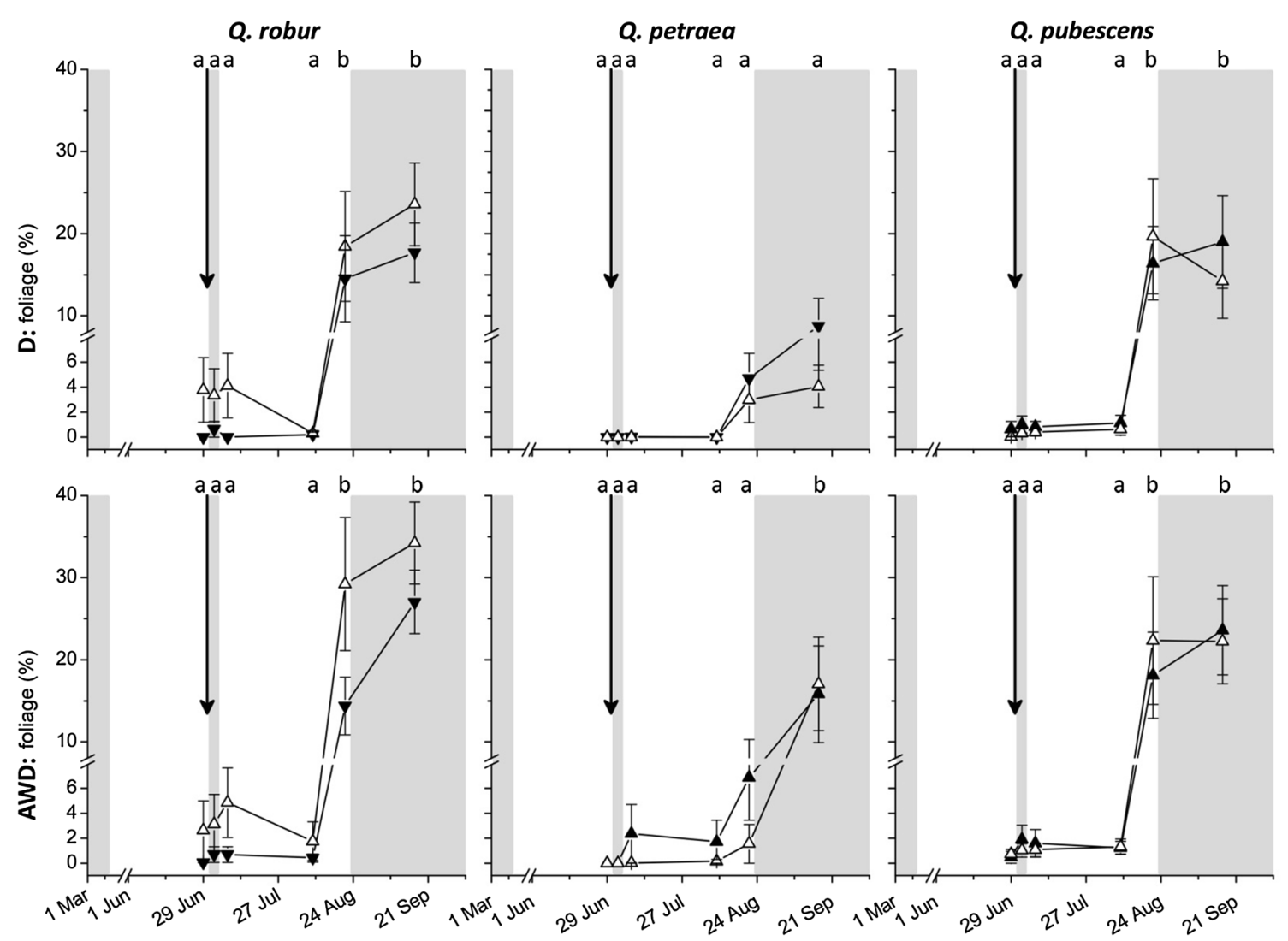

Fig. 2 Development of specific drought stress symptoms in 2009 in foliage of trees from the three tested oak species, growing on the calcareous (open symbols) and acidic (closed symbols) soil type within the drought (D) and combination (AWD) treatment $($ mean $+\mathrm{SE} ; \mathrm{n}=16)$. Periods without and with irrigation in the $\mathrm{D}$

already significant by August 21st $(P<0.001)$. The amounts of specific drought stress symptoms on the calcareous and acidic soil type were similar. Within each species, significant differences between provenances were found in $Q$. petraea $(P=0.05, d f=3)$ and $Q$. pubescens $(P<0.001, d f=3)$ whereas all provenances of $Q$. robur showed similar levels of leaf injury. Differences became significant by September $16^{\text {th }}$ in $Q$. petraea $(P=0.040)$ and as early as July $3 \mathrm{rd}$ in $Q$. pubescens $(P=0.039)$. Concerning the provenances sampled for microscopic analysis, $Q$. petraea Corcelles and $Q$. pubescens Leuk were more symptomatic than the three other provenances from same species $(P=0.03$ and $P \leq 0.02$; there was the same level of injury in all four provenances of $Q$. robur).

\section{Structural injury by drought stress in the leaf blade}

In foliage of trees from AWD treatment, the central and still green part of leaves with or without specific drought stress injury showed various microscopic symptoms with few differences between species and in symptomatic vs. asymptomatic leaves (Table 4). These symptoms were and AWD treatment are indicated with white and grey areas. Different letters on top of each plot indicate significant differences in the percentage of symptomatic foliage between sampling dates, independent of soil type (Tukey HSD; $P \leq 0.05$ ). Black arrows indicate the date of sampling for microscopy (30.06.2009)

generally evenly distributed within large segments of the leaf samples. They were found in most leaf blade and vein tissues and they increased in severity abaxially (Fig. 3). At leaf level, the most striking change was the decreased thickness of intercostal leaf blade segments, as a consequence of cell cytorrhisis, primarily within the lower epidermis and spongy parenchyma (Fig. $3 \mathrm{~b}$ vs. a). Another striking change was the massive-in some samples nearly complete-depletion of starch reserves within mesophyll, whereas the starch grain size and frequency in stomatal guard cells often showed little change (Fig. 3d vs. c).

Within leaf blade tissues, the worst injuries were found in the epidermis, with generally more noticeable symptoms in the lower than upper epidermis (Fig. 4; Table 4). In comparison to samples from control treatment (Fig. 4A, C), large intercostal segments of drought-stressed samples showed various levels of cell plasmolysis and cytorrhisis (Fig. 4B, D), which caused an apparent reduction in cell size. At cell level, the cell content showed several degenerative changes, including the decrease in cytoplasm density (Fig. 4F-H, J) or the disorganization and degradation of organelle structure (Fig. 4F, H, J). These processes were 


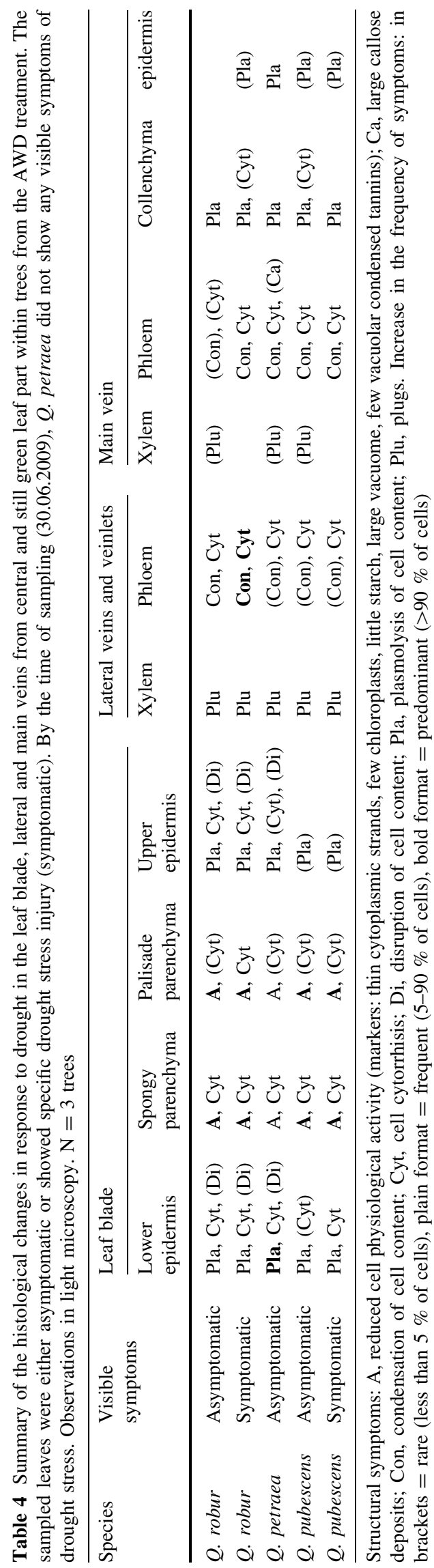

structurally related to increased autophagic activity, as indicated by numerous multivesicular bodies (Fig. 4J, L). The degraded cellular remnants within autophagic vesicles were preferentially discharged in the periplasm by exocytosis, typically next to folded anticlinal cell walls (Fig. 4H, $\mathrm{K}, \mathrm{L}$ ). The cell content of the most degenerated cells was disrupted and only condensed and scattered remnants of cellular material could still be observed (Fig. 4F, H, J). The protoplasm often showed severe plasmolysis (Fig. 4G, J) and occasional cytoplasm strand rupture (Fig. 4G). By contrast, the stomatal guard cells were less affected by these processes and often retained an intact cell structure (Fig. 4F, I vs. E), although the surrounding cells already showed advanced degeneration.

The structural reactions to drought stress in the mesophyll vs. epidermis were partly contrasting. Severe injury was higher in the spongy vs. palisade parenchyma but remained overall lower than in the epidermis (Fig. 5; Table 4). In comparison to the CO treatment, intercostal segments of mesophyll had their thickness decreased as a consequence of cell cytorrhisis, primarily in the spongy and less frequently in the palisade parenchyma (Fig. 3D vs. C, Fig. 5B, D, J vs. A, C). However, cell plasmolysis was never observed. At cell level, structural changes denoted reduced cell physiological activity. Within noncytorrhized cells, the enlarged vacuome was surrounded by thinner cytoplasm strands with fewer organelles (Fig. 5B, D vs. A, C). The condensation of cytoplasm and nucleus was similar to that in control samples whereas that of chloroplasts was slightly enhanced (Fig. 5B vs. A). These latter organelles showed a flatter cross section, slightly thinner grana, little or no starch but an enhanced plastoglobule density (Fig. 5B, D, F vs. A, C, E). Within palisade parenchyma, these symptoms were enhanced adaxially. The vacuole contained none or few condensed tannins but many vesicular inclusions and membranous remnants of degraded structures (Fig. 5D vs. C; Fig. 5I, J). The tonoplast surface was irregular, with invagination and vesiculation denoting extensive autophagic activity (Fig. 5G-J). Microautophagic processes (Bassham et al. 2006; Kwon and Park 2008)—with uptake of cytoplasmic material by tonoplast invaginations prior to transfer and degradation into the vacuole-affected small portions of adjacent cytoplasm (Fig. 5G, J). Macroautophagy processes (Bassham et al. 2006; Kwon and Park 2008), with organelles and parts of cytosol sequestered and mostly degraded within autophagic vesicles (Fig. $5 \mathrm{H}$ ) prior to internalization into the vacuole (Fig. 5I), affected larger parts of cytoplasm. By contrast with processes in epidermis, the discharge of autophagic vesicles in the periplasm was never observed in the mesophyll. Moreover, no callose deposits on cell walls were observed in leaf blade tissues. 


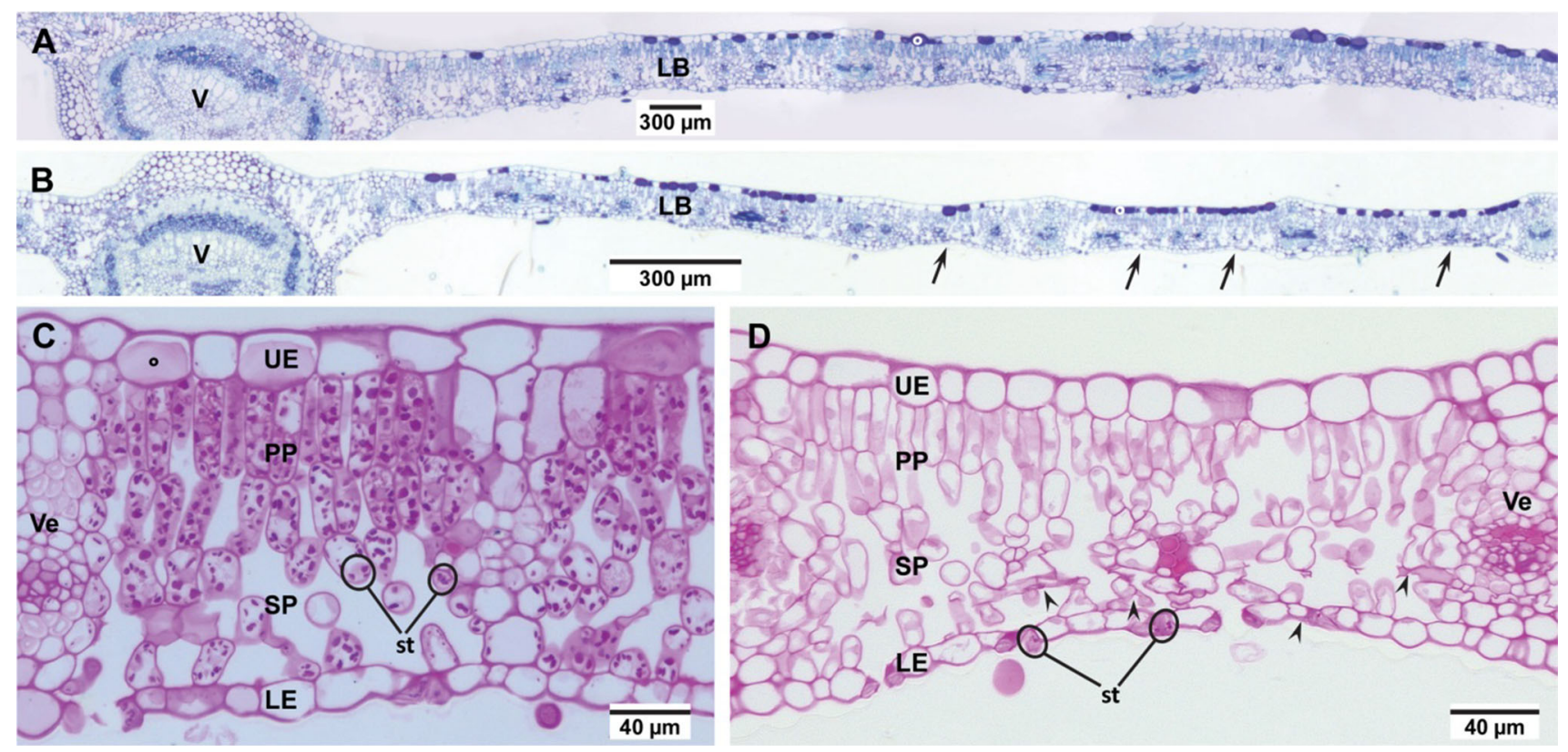

Fig. 3 Structural injury by drought stress at leaf (b) and leaf blade (d) level by the end of first drought period. a, c Asymptomatic samples from the control treatment. Within the drought-stressed samples, the most striking change was the reduction in the leaf blade (LB) thickness (arrows) which was caused by cell cytorrhisis (arrowheads) primarily in the spongy parenchyma (SP) and lower epidermis (LE). Another hallmark of drought stress was the sometimes complete depletion of starch (st) reserves within the palisade

\section{Structural injury by drought stress in veins}

In leaves with or without specific drought stress injury from the AWD treatment, tissues and cells within leaf veins also showed characteristic structural changes in response to drought stress. In xylem, the water conducting elements were often plugged by amorphous material filling the cell lumen and cell wall punctuations. This material was primarily made of insoluble polysaccharides-mainly pectin, as shown by specific staining using PARS and coriphosphine (Table 3; Fig. 6E, F). Cellulose, callose, lignin, condensed tannins, protein, or lipid fractions were not found, as indicated by negative or unspecific staining using Calcofluor White Mr2, Aniline blue, Phloro-glucinol, $\mathrm{H}_{2} \mathrm{SO}_{4} 3 \mathrm{M}$, Coomassie brilliant blue and Sudan-black B, respectively (Table 3; results not shown).

In the phloem, cells were showing cytorrhisis and cell content condensation, with little difference between the assimilate-collection (Fig. 6D vs. B) and -transport (Fig. 6C vs. A) phloem within minor and major veins (Evert 2006). At cell level, the companion cell structure within minor veins was typical of that found in open veinlets of type 1, as reported for Fagaceae (Evert 2006; Gamalei 1989) and other passive phloem loading species (Slewinski et al. 2013). Its characteristic traits within
(PP) and spongy parenchyma whereas starch grains could still be observed within stomatal guard cells of lower epidermis (d vs. c). At the time of sampling, the leaves used for excising the $\mathbf{b}$ and $\mathbf{d}$ samples were still asymptomatic. Other structures: $V$ main leaf vein, $V e$ veinlet, $U E$ upper epidermis, ${ }^{\circ}$ epidermal cells filled with polysaccharides releasable in apoplast as a defense response against insect piercing (authors' observations). These dead cells were not affected by drought stress. Species: Quercus pubescens

leaves from $\mathrm{CO}$ samples included (1) abundant symplastic contact with surrounding cells through plasmodesmata sometimes grouped in fields, (2) very dense cytoplasm partly due to the high ribosome/polysome density, (3) numerous mitochondria, (4) abundant rough endoplasmic reticulum, (5) small vacuoles, (6) few plastids containing no starch and (7) a prominent nucleus (Fig. 5G, J). Companion cells were also larger than their associated sieve tubes (Fig. 5G, J, M). By contrast in companion cells from AWD samples, cytorrhisis, plasmolysis, condensation of the cell content (with cytoplasm, organelles and nucleus structure being mostly indistinct) and an increase in the vacuome size and autophagic activity were observed (Fig. 6H, L, O vs. G, J). Functional sieve tubes within leaves from $\mathrm{CO}$ samples showed a mostly clear lumen with the remaining organelles, P-proteins and a lattice-like and complex network of smooth endoplasmic reticulum lying next to the plasmalemma (Fig. 6I, J). In AWD samples, sieve tubes similar to their companion cells also showed plasmolysis and cytorrhisis (Fig. 6H, K, N vs. G, I, M). Moreover, the material normally lying along plasmalemma was dispersed through the lumen which appeared obstructed by mostly fibrillar structures (Fig. 6K), reminiscent of dispersed P-proteins (Eschrich 1995; Evert 2006). This assumption was ascertained histochemically 

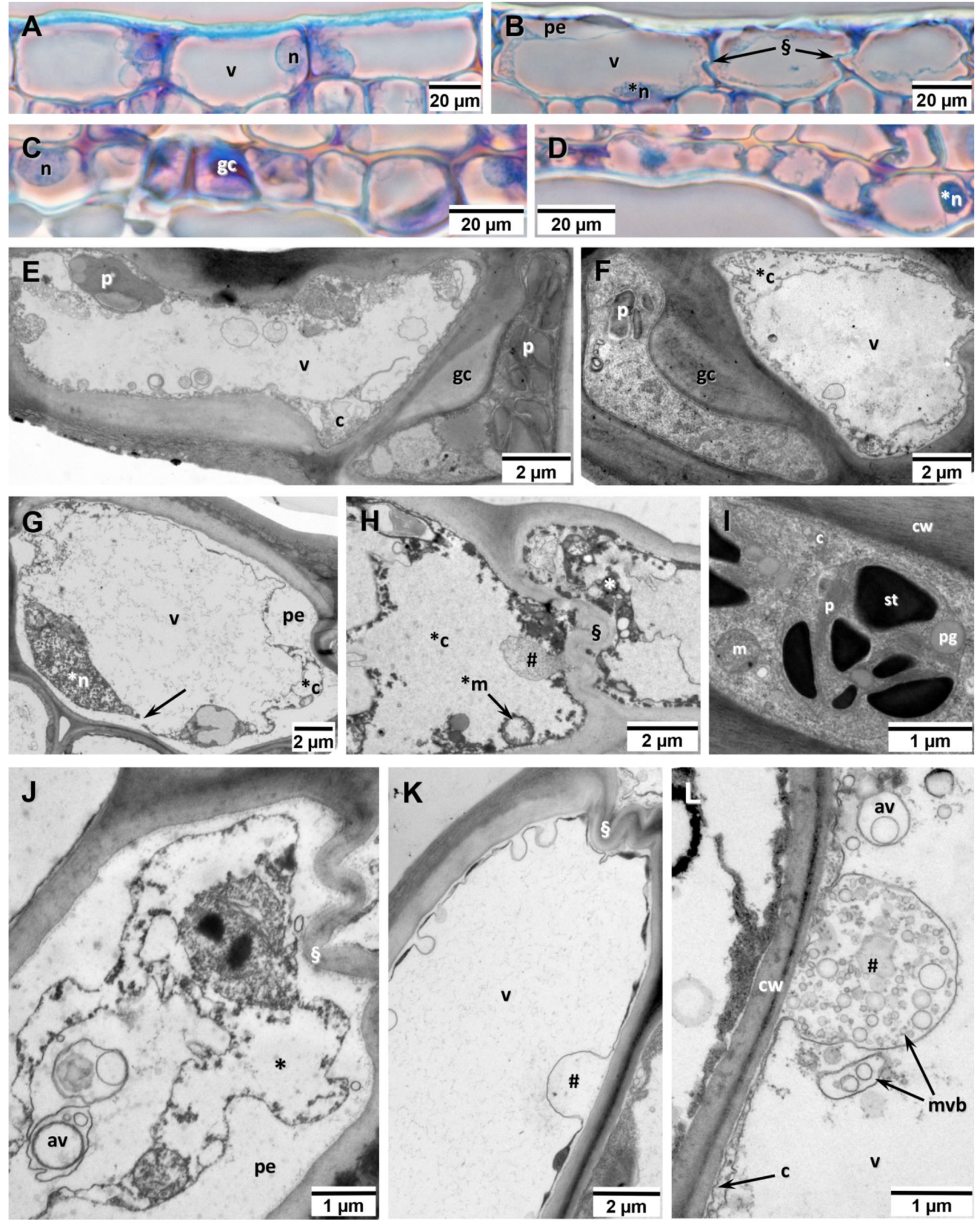
4Fig. 4 Microscopic symptoms of drought stress in upper $(\mathbf{A}, \mathbf{B}, \mathbf{G}$, $\mathbf{L})$ and lower $(\mathbf{C}-\mathbf{F}, \mathbf{H}-\mathbf{K})$ epidermis, at tissue (A-D) and cell $(\mathbf{E}-$ L) level. A, C, E Asymptomatic samples from the control treatment. Stressed epidermis cells showed plasmolysis (B, D, G, J) and/or cytorrhisis, as indicated by reduction in the cell size (D vs. C) and folds (section symbol) in the anticlinal cell walls $(\mathbf{B}, \mathbf{H}, \mathbf{J}, \mathbf{K})$. The cell content showed a decrease in the cytoplasm density $(* \mathrm{c} ; \mathbf{F}-\mathbf{H}, \mathbf{J})$, the degeneration of organelles ( ${ }^{*} \mathrm{n},{ }^{*} \mathrm{~m} ; \mathbf{B}, \mathbf{D}, \mathbf{H}, \mathbf{J}$ vs. E) and a higher frequency of multivesicular bodies (mvb), a marker of increased autophagic activity (J-L). The remnants of cell material (hash) within autophagic vesicles (av) were preferentially discharged by exocytosis in the periplasm (pe) and typically next to anticlinal cell walls $(\mathbf{H}, \mathbf{K}$, L). At an advanced degeneration stage, the cell content appeared disrupted (asterisk; F, H, J) with condensed and indistinct cell remnants (H) and ruptured cytoplasmic strands (arrow in G). By contrast, stomatal guard cells $(\mathrm{gc})$ within lower epidermis often retained a nearly intact cell structure (F vs. E), as indicated by a dense cytoplasm (c) or plastids (p) with large starch grains (st, I). Other structures: cw: cell wall, m: mitochondria, n: nucleus, pg: plastoglobule, v: vacuole. Species: Quercus robur $(\mathbf{D}, \mathbf{H}, \mathbf{I}, \mathbf{L}), Q$. petraea $(\mathbf{A}$, $\mathbf{B}, \mathbf{C}, \mathbf{G}, \mathbf{K}), Q$. pubescens $(\mathbf{E}, \mathbf{F}, \mathbf{J})$

using Coomassie brilliant blue staining (Table 3) and light microscopy. The healthy sieve tubes generally showed a weak protein signal primarily at the cell periphery (Fig. 6M). In degenerated sieve tubes, the protein signal was more intense and more homogeneously distributed (Fig. 6N). Hence, proteins and fibrillar structures showed similar distribution patterns within sieve tubes. Callose accumulation was only occasionally observed in sieve tubes of midrib from $Q$. petraea samples (Tables 3, 4).Within tissues surrounding the vascular bundle of midrib, plasmolysis and occasional cytorrhisis was observed in epidermis and collenchyma (Table 4).

\section{Severity of injury at tissue and species level}

Regarding the injury severity and cell vitality, symptoms as advanced plasmolysis (Figs. 4B, D, J, 6K, L, O), cytorrhisis (Figs. 4J, 5B, 6C, D, K, N) cell content disruption (Figs. 4G, $\mathrm{H}, \mathrm{J}, 6 \mathrm{H}, \mathrm{K}$ ) or condensation of cell remnants (Figs. 4G, H, J, 6L, O) meant cell death (Kroemer et al. 2005). Accordingly, and as shown in Table 4, structural changes to be found in lower epidermis (Fig. 4D, F, G, H, J-L), spongy parenchyma (Fig. 5B, J) or phloem (Fig. 6C, D, H, K, L, N, O) were more severe than those to be found in stomata cells (Fig. 4F, I) and palisade parenchyma (Fig. 5B, D, F, I). The secondary veins and other higher order veinlets were more affected by drought stress than the midrib.

Within the still asymptomatic central part of leaves, the injury severity was the principal difference to be found between oak species whereas the type and distribution pattern of injury were similar (Table 4). Q. petraea, the species showing the smallest amount of visible injury (Fig. 2), had also the least affected mesophyll, whereas injuries in veins were overall similar to those in $Q$. pubescens and less severe than those in $Q$. robur. In the leaf blade, the cellular integrity of upper and lower epidermis was better retained in $Q$. pubescens than in other species. The severest injuries and lowest cell viability were observed in $Q$. robur. Symptomatic vs. asymptomatic leaves only showed slightly enhanced injury (Table 4).

\section{Discussion}

\section{Visible symptoms specific of drought stress}

The development of gradients of leaf margin necrosis can be regarded as the turning point from tolerant to intolerant reactions in oak foliage. At the time of sampling, the soil water deficit represented the limit beyond which the development of irreversible damage-i.e., necrosis-prevailed. Physiologically, the gas exchanges had then nearly ceased and the leaf water potential dropped to very low values. Given the moderate level of warming in Querco and positive physiological responses of oak leaves in the AW vs. CO treatment, an eventual contribution of heat stress with regard to the development of injury in foliage can be excluded. Specific drought stress injury was diagnosed in 2008 for the first time within a few trees from the D and AWD treatment (Günthardt-Goerg et al. 2013). Since this type of injury had just shown up in $Q$. robur and $Q$. pubescens by the time of sampling for microscopy (whereas it did not develop until the beginning of 2 nd drought period in $Q$. petraea), the adaptive changes in the cell and tissue structure observed in still intact parts of symptomatic foliage represent advanced adaptive reactions shortly before the terminal degeneration of cells and tissues.

\section{Structural and ultrastructural changes in symptomatic foliage}

A broad range of drought stress symptoms were observed in most living tissues and cell types of leaf blade, minor and major veins. Taken as a whole, structural changes like (1) cytorrhisis, (2) plasmolysis, (3) the multiplication of cytoplasmic vesicles, (4) the decrease in the size and abundance of starch grains or (5) the increased plastoglobule density are typical of drought stress within foliage fully differentiated prior to drought (Fink 1999). Together with the enlargement of vacuome or changes in the chloroplast shape, these microscopic changes have typically been reported for mesophyll cells (**Olmos et al. 2007; Pääkkönen et al. 1998; Vassileva et al. 2012; Zellnig et al. 2010) whereas the vein network can also show drought stress symptoms (Fink 1999). We observed important differences in injury severity between sometimes adjacent cell types, not only in different but also within the 

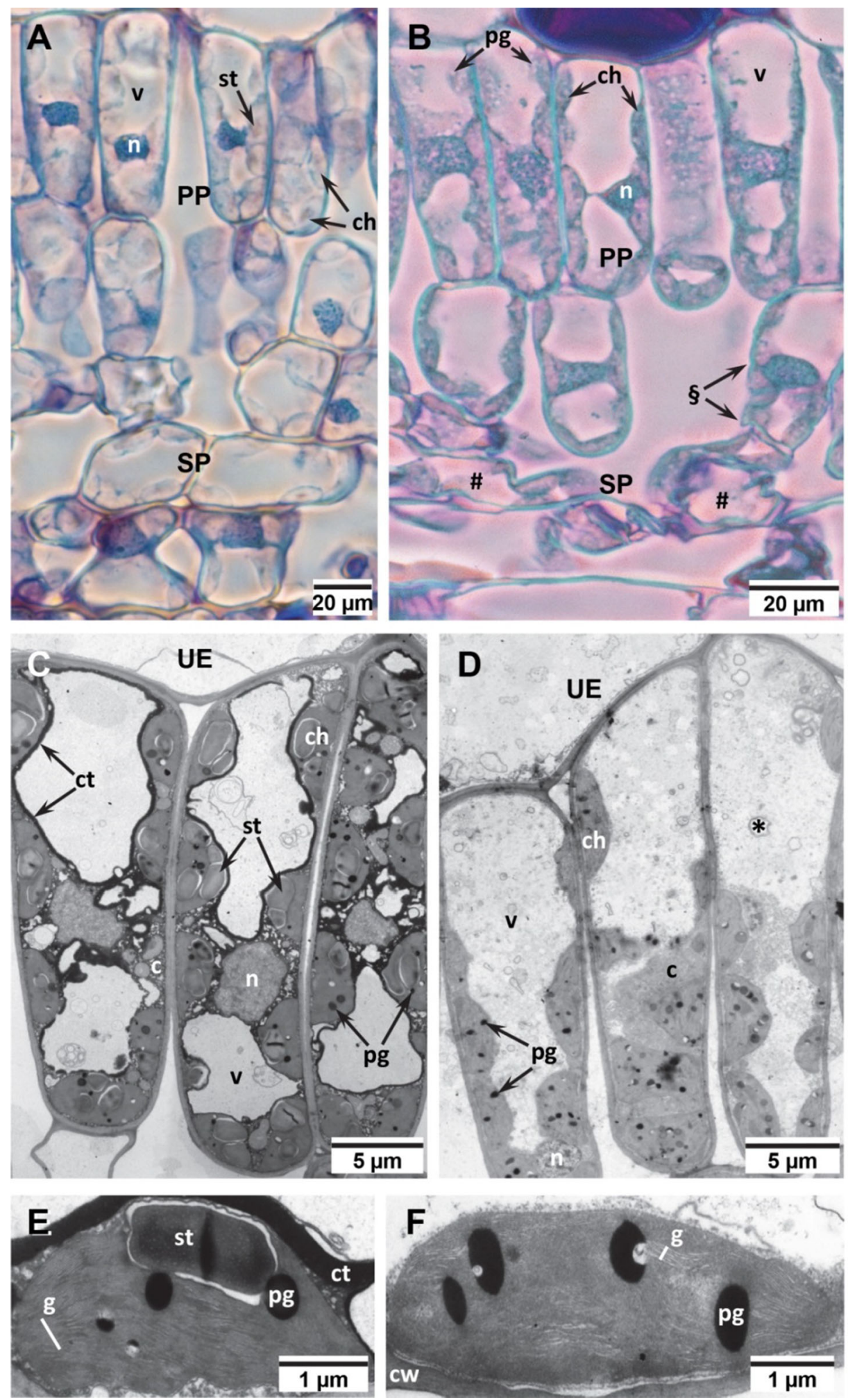
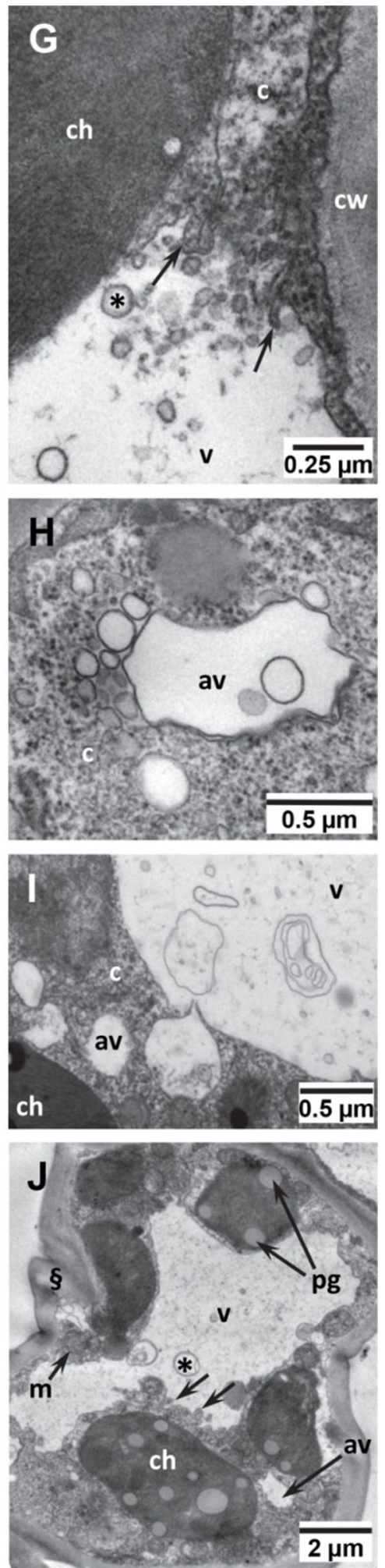
4 Fig. 5 Microscopic symptoms triggered by drought stress in palisade (A-F, I) and spongy (A, B, G, H, J) parenchyma at tissue (A, B), cell $(\mathbf{C}, \mathbf{D}, \mathbf{J})$ and subcellular level (E-I). A, C, E Asymptomatic samples from control treatment. B, D vs. A, C In drought-stressed samples and primarily within the spongy parenchyma (SP), cell cytorrhisis (hash) caused folds (section symbol) in cell walls and an apparent reduction in the cell size. Other mesophyll cells showed an enlarged vacuome (v) and thinner cytoplasm (c) layer with less organelles. The vacuole contained no condensed tannins (ct) but many vesicular inclusions (asterisk). The chloroplasts (ch), but not the nucleus (n) or cytoplasm, appeared slightly more condensed. $\mathbf{F}$ vs. $\mathbf{E}$ Chloroplasts in adaxial palisade parenchyma (PP), just below upper epidermis cells. These organelles showed a flatter cross section, slightly thinner grana $(\mathrm{g})$, little or no starch (st) but an increased plastoglobule (pg) density. Extensive micro- $(\mathbf{G}, \mathbf{J})$ and macro-autophagy $(\mathbf{H}, \mathbf{I})$ processes contributed to vacuome enlargement. G Tonoplast invaginations (arrows, also in $\mathbf{J}$ ) sequestered portions of cytoplasm which were degraded in the vacuole and the vesicular inclusions (asterisk) became electron-translucent. Autophagic vesicles (av) developed directly in the cytoplasm $(\mathbf{H})$ and engulfed organelles and parts of cytosol which were then mostly degraded prior to internalization in the vacuole (I). J Cytorrhized spongy parenchyma cell. Other structures: cw: cell wall, m: mitochondria, UE: upper epidermis. Species: Quercus robur (I), Q. petraea (A), Q. pubescens $(\mathbf{B}, \mathbf{C}-\mathbf{H}, \mathbf{J})$

same leaf tissues. The cell structure could, thus, be almost intact (guard cells), altered, but retaining its compartmentation and probably also its functionality (palisade parenchyma), severely damaged (spongy parenchyma, conducting phloem cells) and frequently necrotic (epidermis cells), as indicated by extensive autophagic processes and cell content disruption (Kroemer et al. 2005). These symptoms were altogether typical of reactions to acute summer drought (Fink 1999) and they indicated that water stress was effective only by the end of drought period, after full differentiation of foliage in first-flush shoots. This conclusion is supported by the physiological measurements of leaf water potential and gas exchanges, which showed no significant drought effect before the end of May (Arend et al. 2013). Such a delay in the treatment effect relates to the large volume of the lysimeters at the model ecosystem facility of WSL and the extensive development of the oak root system after 3 years of growth in the facility (Kuster et al. 2013b).

Symptoms like cytorrhisis, plasmolysis or tonoplast invagination/vesiculation were indicative of disturbed osmotic homeostasis and cell dehydration, in agreement with the low leaf water potential by the time of sampling. The depletion of starch reserves was consistent with the large assimilation decrease measured shortly before sampling. Together with autophagic processes, they denoted the increasing scarcity of carbon substrates. However, these processes, primarily the increased autophagic activity, were also indicative of the cell-level mechanisms to maintain the cell viability and adapt the cell structure to the increasingly constrained availability of water and carbon resources. The varying implementation and efficiency of these mechanisms in different cell types prominently contributed to the variability of symptom expression at tissue and cell level.

In the leaf blade, three different morphological types of autophagy (i.e., autophagy associated with exocytosis, micro- and macroautophagy) contributed to the rearrangement of the cell structure in various ways. As catabolic processes participating to developmental, defense or senescence responses, the other roles of autophagy usually include the degradation of obsolete structures, neutralization of toxic compounds or retrieval of nutrients (Bassham et al. 2006; Kwon and Park 2008; Marty 1999; Wang et al. 2010). In droughted oak foliage, epidermis cell walls may be stiffened by exocytosis and the non-stomatal transpiration, lowered. As a trade-off, however, the ensuing depletion of carbon substrates from protoplasm could accelerate epidermis cell starvation and, probably, cell death too. By contrast in mesophyll cells, macro- and microautophagy processes could alleviate carbon starvation and provide substrates for sustained respiratory activity (Marty 1999; Moriyasu and Klionsky 2004). Different to the epidermis, these processes could also contribute to raising the solute concentration and lowering the osmotic potential, which apparently prevented plasmolysis. Osmotic adjustments in response to drought are particularly well developed in oaks (Abrams 1990). Such adjustments were also indicated by vesiculation in plasmalemma and tonoplast or the increased size of vacuome. Micro- and macroautophagy could also contribute to accelerating cell senescence, as indicated by leaf yellowing (Günthardt-Goerg et al. 2013) and transient chlorophyll content decrease by the end of the drought period (Arend et al. 2013).

Changes in the chloroplast structure, such as the higher plastoglobule density or condensation of stroma, and adaxial symptom enhancement in palisade parenchyma were indicative of increased photo-oxidative stress. They were consistent with slight transient change in chlorophyll fluorescence and concentration, relieved by rewatering (Arend et al. 2013). Increased plastoglobule density denoted higher lipid trafficking and thylakoid membrane turnover (Bréhélin et al. 2007; Tevini and Steinmüller 1985). Together with the condensation of chloroplast stroma, this trait is frequently observed in response to increased oxidative stress (Günthardt-Goerg et al. 2007; Soda et al. 2000; Vollenweider et al. 2013). Compared to other symplastic sites indeed, chloroplasts are a major source of Reactive Oxygen Species (ROS) and they are prone to oxidative damage (Kangasjarvi et al. 2005; Sandermann 1996; Yamasaki et al. 1997). Drought can induce oxidative stress (Munné-Bosch and Peñuelas 2004; Noctor et al. 2002) and the increase in severity of the injury with better chloroplast illumination was indicative of enhanced photooxidative stress (Foyer et al. 1994; Vollenweider 

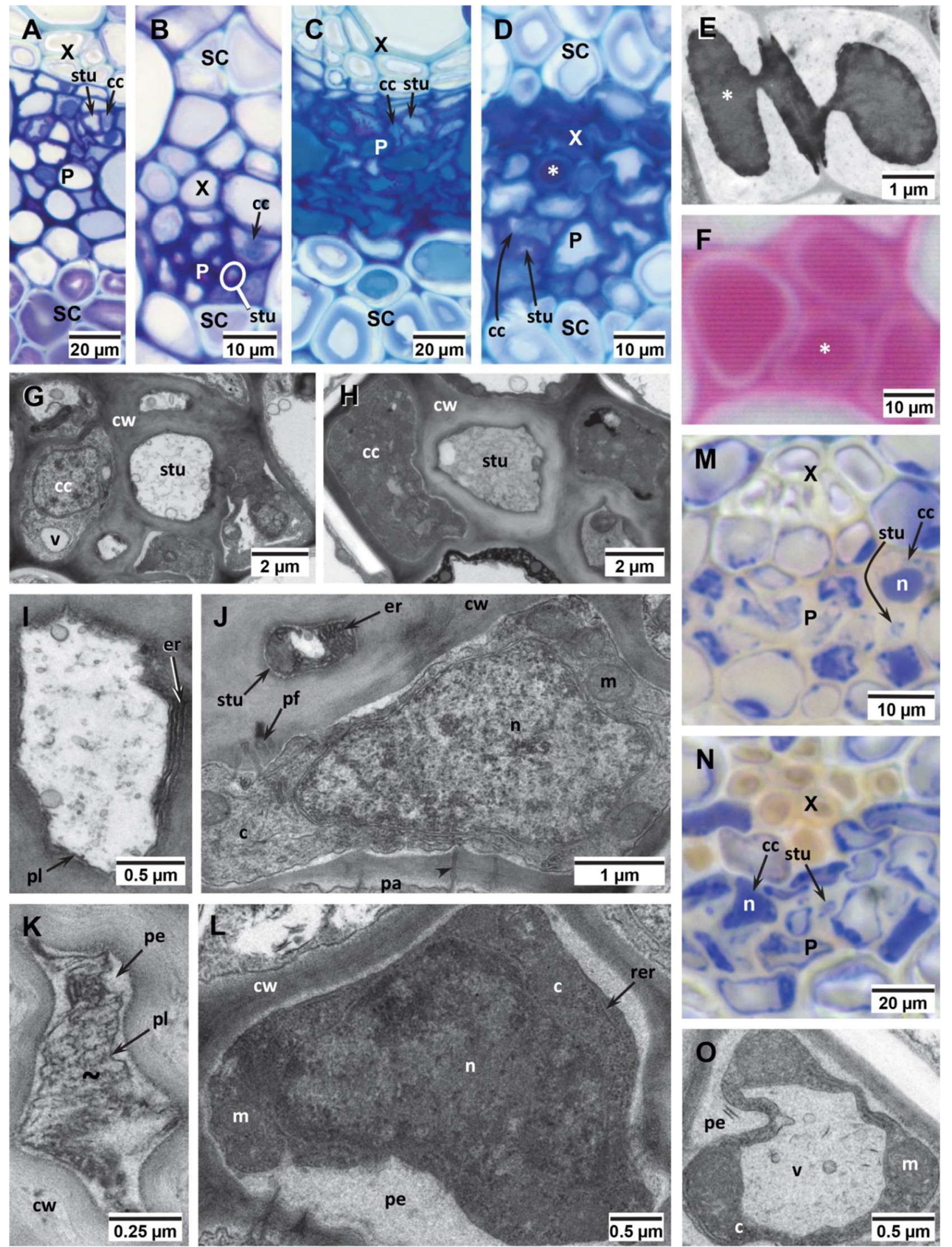
४Fig. 6 Microscopic symptoms triggered by drought stress in conducting tissues of midrib $(\mathbf{A}, \mathbf{C})$ and lateral veins $(\mathbf{B}, \mathbf{D}-\mathbf{O})$, at tissue $(\mathbf{A}-\mathbf{D}, \mathbf{G}, \mathbf{H}, \mathbf{M}, \mathbf{N})$ and cell level $(\mathbf{E}, \mathbf{F}, \mathbf{I}-\mathbf{L}, \mathbf{O}) . \mathbf{A}, \mathbf{B}, \mathbf{G}, \mathbf{I}, \mathbf{J}$, M Asymptomatic samples from control treatment. C, D vs. A, B In drought-stressed vs. control samples, the conducting tissues showed several injuries including cell cytorrhisis, as indicated by cell wall folds, and the condensation of cell content in phloem $(\mathrm{P})$, whereas the water-conducting elements in xylem $(\mathrm{X})$, primarily of minor veins, were obstructed with plugs (asterisk). E, F Plugs fully and homogeneously obstructed the xylem cell lumen and were made of amorphous polysaccharidic (mostly pectin) material. H vs. G Structural changes caused by drought stress in assimilate-collection phloem. Sieve tubes (stu) and companion cells (cc) shared a similar fate but the degenerative structural changes were specific to each cell type. $\mathbf{K}$ vs. I, $\mathbf{G}$ Degenerated sieve tubes showed cytorrhisis and plasmolysis. The cell lumen was obstructed by mostly fibrillar structures (tilde symbol) and the lattice-like network of smooth endoplasmic reticulum (er) next to plasmalemma (pl) was missing completely. $\mathbf{L}, \mathbf{O}$ vs. J Companion cells were also cytorrhized and plasmolyzed but the cell content was not disrupted. Cytoplasm (c) and organelles appeared highly condensed and rather indistinct and vacuoles (v) were enlarged. $\mathbf{N}$ vs. $\mathbf{M}$ Change in the distribution of proteins (in blue) within sieve tubes. In comparison to healthy cells, the signal was stronger and more homogeneously distributed in the cell lumen. Other structures: $\mathrm{cw}$ : cell wall, m: mitochondria, $\mathrm{n}$ : nucleus, pa: parenchyma cells, pe: periplasm, rer: rough endoplasmic reticulum, SC: sclerenchyma, Histochemical revelation: PARS for insoluble polysaccharides (F), Coomassie brilliant blue for proteins $(\mathbf{M}, \mathbf{N})$. Species: Quercus robur $(\mathbf{C}-\mathbf{F}, \mathbf{K}, \mathbf{L}, \mathbf{O})$, Q. petraea $(\mathbf{A}, \mathbf{B}, \mathbf{G}-$ $\mathbf{J}, \mathbf{M})$, Q. pubescens $(\mathbf{N})$

et al. 2013). A low availability of carbon substrate for defense, as suggested by the apparent decrease of vacuolar tannins, might also contribute to decreased detoxification capacity. Based on ultrastructural injury, however, oxidative stress in chloroplasts was less severe than observed in the case of metal or ozone stress factors (Hermle et al. 2007; Vollenweider et al. 2013).

Physiological processes identifiable in major and minor veins partly differed from those observed in the leaf blade. Plugs obstructing the water-conducting elements in xylem were ultrastructurally and histochemically similar to mucilage-like polysaccharidic material accumulated in the epidermis of oaks (Fig. 3) and other species (Eschrich 1995) for defense purposes (authors' observations). In foliage experiencing severe drop of the leaf water potential, they appear as an alternative to the collapse of xylem cells (Cochard et al. 2004). By shutting off part of the veinlet network, plugs might contribute to reducing the demand for water and preserving the remaining veinlet network. In the phloem, companion cells and sieve tubes showed different structural changes. Whilst degenerative processes, rather similar to those in mesophyll, were observed in companion cells, the sieve tubes were clogged by P-proteins released from the parietal endoplasmic reticulum conduits. Interestingly, such reactions in the phloem are unspecific and can be triggered by various stress factors (Evert 2006).
Hence, both xylem and phloem lost their conductive functionality but through distinct degenerative processes.

\section{Tolerant and intolerant reactions at tissue and cell level}

Taken as a whole, the degenerative processes observed in the leaf blade and veins appeared to proceed in an orderly, and thus programmed way, with the irreversible reactions observed first in less essential tissues and cell types (lower and upper epidermis cells) and a prioritization of cell types primarily in charge of leaf assimilation (stomata and upper mesophyll). By supplying mesophyll with carbon substrates and vacuolar solutes, processes like macro- and microautophagy could contribute to prolonged tolerance. Similar to reactions in drought-tolerant vs. -sensitive cultivars of herbaceous plants, effective tolerance was also indicated by the generally well retained chloroplast structure and missing disruption of envelope or thylakoid swelling (Ristic and Cass 1991). By contrast and as observed primarily in epidermis cells, markers of intolerant reactions included the (1) advanced degradation of cytoplasmic content, (2) frequent rupture of tonoplast, plasmalemma and cytoplasm strands and (3) advanced plasmolysis and cytorrhisis. Given the range of reactions and symptom severity observed in oak foliage and based on structural markers, the sequence of cellular responses to drought stress can be thus summarized within a conceptual model (Fig. 7). Confronted with a water and carbon shortage, processes such as the osmotic homeostasis, storage of assimilates or repair/defense appeared to be primarily affected. In a first-probably reversible-stage, cells rearranged their cellular machinery, specifically through autophagic processes. These cell physiological responses could enhance tolerance and slow down the degenerative processes. Meanwhile, cells suffered from a probably lesser repair and defense capacity, as indicated by increased photo-oxidative injury. In a later and certainly irreversible stage, cell content degeneration and disruption took over and led to cell death.

However, the orderly sacrifice of given cell types (e.g., epidermis cells) could benefit tolerance at higher morphological-i.e. leaf-level. By its contribution to cell wall thickening and cell death, exocytosis thus tended to enhance the xeromorphic traits in epidermis cells which, in xerophytic plants, are generally dead after developing thick lignified cell walls (Fink 1999). Prioritization of more essential leaf parts is also suggested by the more severe drought stress injury observed in lateral veins vs. midrib. Similarly in other studies, more vulnerability to drought stress was observed in higher vs. lower order veinlets, especially those at leaf periphery (Salleo et al. 2001). 


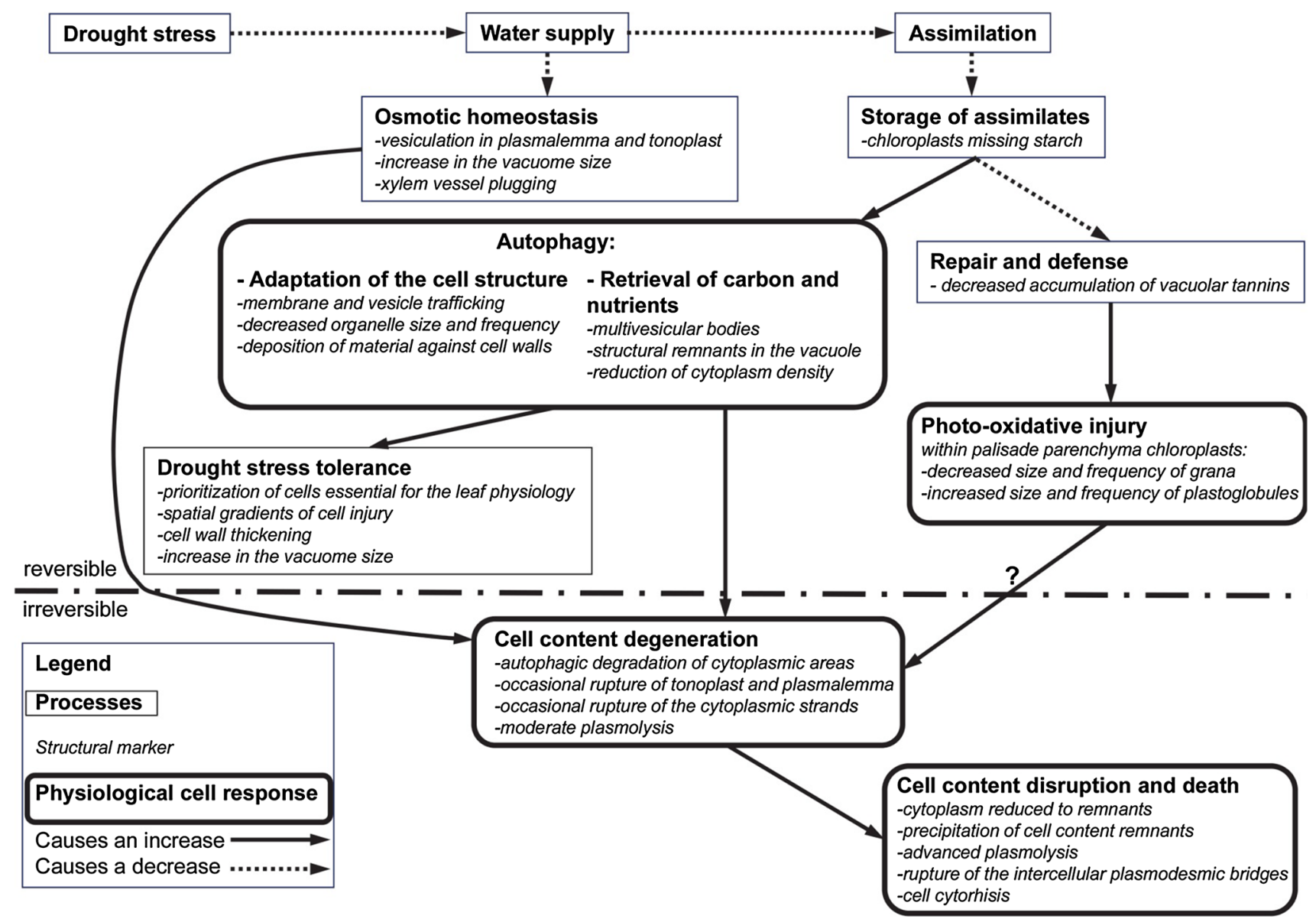

Fig. 7 Conceptual model of the physiological cell responses to drought stress and associated processes, as indicated by structural changes in the leaf cell structure within oak foliage showing specific

\section{Relationship between microscopical and visible injury}

Intolerant and tolerant structural reactions within leaf tissues and cells provide key insights on the visible injury and other reactions in foliage during the Querco experiment. Obstruction of conducting phloem and xylem cells in veinlets was probably a main contributor to the development of necrotic leaf rims. The gradients of injury severity between the leaf center and periphery or between younger and older leaves could denote leaf-level mechanisms of prioritization completing those identified within cells and tissues. Within leaves, such prioritization can explain how oak foliage resumed gas exchange within hours after rewatering (Arend et al. 2013). This response has been frequently observed in oaks (Dickson and Tomlinson 1996) and may be mechanistically related to their close control of stomatal gas exchange. Given the structural responses within the still asymptomatic leaf parts, the morphology of specific drought stress injury thus appears related to drought stress injury. Validity range: all living cell types within leaves except the specialized companion cell/sieve tube complex in phloem

tolerance reactions, with the development of irreversible necrosis still restrained to the marginal parts of tree foliage.

\section{Conclusion}

Structural changes at cell, tissue and leaf level shed light on the effects of acute summer drought and the micromorphological responses in mature foliage of oaks to drought stress. They were indicative of water shortage and carbon starvation and of the plant reactions to maintain cell homeostasis. However, the microscopic markers and the injury severity within different tissues and cell types showed variation relating to the specific role of each cell type. Tolerance mechanisms included (1) the increase of vacuolar volume and activity-and presumably solute concentration - partly through (2) the release of solutes and carbon substrates by the autophagic degradation of cytoplasm components and (3) the prioritization of cell types primarily involved in gas exchange and assimilation. 
Irreversible leaf injury was thus preceded by extensive rearrangement of the cell structure within most tissues and this contributed to delay, and probably reduce, visible injury and shedding of tree foliage. These processes played a key role regarding the recovery of gas exchange and assimilation in foliage, after resumption of the irrigation.

Author contribution statement PV: study PI/microscopic analysis/paper writing, TM: microscopic analysis/technical assistance, MA: ecophysiological assessments/paper writing, ThK: assessments of environmental conditions/paper writing, MGG: Experiment PI/paper writing.

Acknowledgments Technical assistance and support by trainees, microscopy apprentices and the Center for Microscopy and Image Analysis of the University of Zurich are gratefully acknowledged.

\section{Compliance with ethical standards}

Conflict of interest Authors certify that there is no actual or potential conflict of interest in relation to this article.

\section{References}

Abrams MD (1990) Adaptations and responses to drought in Quercus species of North America. Tree Physiol 7:227-238

Abrams MD, Kubiske ME (1990) Leaf structural characteristics of 31 hardwood and conifer tree species in central WisconsinInfluence of light regime and shade tolerance rank. For Ecol Manage 31:245-253

Allen CD, Macalady AK, Chenchouni H, Bachelet D, McDowell N, Vennetier M, Kizberger T, Rigling A, Breshears DD, Hogg EH, Gonzalez P, Fensham R, Zhang Z, Castro J, Demidova N, Lim JH, Allard G, Running SW, Semerci A, Cobb N (2010) A global overview of drought and heat-induced tree mortality reveals emerging climate change risks for forests. For Ecol Manage 259:660-684

Arend M, Kuster T, Günthardt-Goerg MS, Dobbertin M (2011) Provenance-specific growth responses to drought and air warming in three European oak species (Quercus robur, Q.petraea and Q.pubescens) Tree Physiol 31:287-297

Arend M, Brem A, Kuster TM, Gunthardt-Goerg MS (2013) Seasonal photosynthetic responses of European oaks to drought and elevated daytime temperature. Plant Biol. 15(Suppl 1):169-176

Bassham DC, Laporte M, Marty F, Moriyasu Y, Ohsumi Y, Olsen LJ, Yoshimoto K (2006) Autophagy in development and stress responses of plants. Autophagy 2:2-11

Bey I, Croci-Maspoli M, Fuhrer J, Kull C, Appenzeller Ch, Knutti R, Schär Ch J (2011) Swiss Climate Change Scenarios CH2011. C2SM, MeteoSwiss, ETH, NCCR Climate, OcCC (2011) http:// dx.doi.org/10.3929/ethz-a-006720559

Bréda N, Huc R, Granier A, Dreyer E (2006) Temperate forest trees and stands under severe drought: a review of ecophysiological responses, adaptation processes and long-term consequences. Ann For Sci 63:625-644

Bréhélin C, Kessler F, van Wijk KJ (2007) Plastoglobules: versatile lipoprotein particles in plastids. Trends Plant Sci 12:260-266

Brundrett MC, Kendrick B, Peterson CA (1991) Efficient lipid staining in plant material with sudan red 7B or fluoral yellow 088 in polyethylene glycol-glycerol. Biotech Histochem 66:111-116

CH2014-Impacts (2014) Toward Quantitative Scenarios of Climate Change Impacts in Switzerland, published by OCCR, FOEN,
MeteoSwiss, C2SM, Agroscope, and ProClim, Bern, Switzerland, $136 \mathrm{pp}$

Clark G (1981) Staining procedures, 4th edn. Williams \& Wilkins, Baltimore

Cochard H, Froux F, Mayr S, Coutand C (2004) Xylem wall collapse in water-stressed pine needles. Plant Physiol 134:401-408

Cruiziat P, Cochard H, Améglio T (2002) Hydraulic architecture of trees: main concepts and results. Ann For Sci 59:723-752

Dai A (2011) Drought under global warming: a review. Wiley Interdisciplinary Reviews: Climate Change 2(1):45-65. doi:10. $1002 /$ wcc. 81

Defila C, Clot B (2001) Phytophenological trends in Switzerland. Int J Biometeorol 45:203-207

Dickson RE, Tomlinson PT (1996) Oak growth, development and carbon metabolism in response to water stress. Ann Sci For 53:181-196

Eschrich W (1995) Funktionelle Pflanzenanatomie. Springer-Verlag, Berlin, Heidelberg, New York

Evert RE (2006) Esau's plant anatomy. Wiley, Hoboken

Feder N, O'Brien TP (1968) Plant microtechnique: some principles and new methods. Am J Bot 55:123-142

Fink S (1999) Pathological and Regenerative Plant Anatomy. Borntraeger, Berlin, Stuttgart

Foyer CH, Lelandais M, Kunert KJ (1994) Photooxidative stress in plants. Physiol Plant 92:696-717

Gahan PB (1981) Cell senescence and death in plants. In: Bowen ID, Lockshin RA (eds) Cell death in biology and pathology. Chapman and Hall, London, New York, pp 145-170

Gamalei Y (1989) Structure and function of leaf minor veins in trees and herbs. A taxonomic review. Trees 3:96-110

Gerlach D (1984) Botanische Mikrotechnik, 3rd edn. Thieme Verlag, Stuttgart

Grill D, Tausz M, Pöllinger U, Jiménez MS, Morales D (2004) Effects of drought on needle anatomy of Pinus canariensis. Flora 199:85-89

Günthardt-Goerg MS, Vollenweider P (2007) Linking stress with macroscopic and microscopic leaf response in trees: new diagnostic perspectives. Environ Pollut 147:467-488

Günthardt-Goerg MS, Kuster TM, Arend M, Vollenweider P (2013) Foliage response of young central European oaks to air warming, drought and soil type. Plant Biol 15(Suppl 1):185-197

Gutmann M (1993) Localization of proanthocyanidins using in situhydrolysis with sulfuric acid. Biotech Histochem 68:161-165

Hartmann G, Nienhaus F, Butin H (2007) Farbatlas Waldschäden. 3. Auflage. Diagnose von Baumkrankheiten. 3. Auflage. Eugen Ulmer KG, Stuttgart

Hermle S, Vollenweider P, McQuattie CJ, Matyssek R, GünthardtGoerg MS (2007) Leaf responsiveness of field-grown Populus tremula and Salix viminalis to soil contamination by heavy metals and rainwater acidity. Tree Physiol 27:1517-1531

IPCC (2014) Climate Change 2014: Synthesis Report. Contribution of Working Groups I, II and III to the Fifth Assessment Report of the Intergovernmental Panel on Climate Change [Core Writing Team, R.K. Pachauri and L.A. Meyer (eds.)]. IPCC, Geneva, Switzerland, $\mathrm{p} 151$

Kangasjarvi J, Jaspers P, Kollist H (2005) Signalling and cell death in ozone-exposed plants. Plant Cell Environ 28:1021-1036

Kivimäenpää M, Jonsson AM, Stjernquist I, Sellden G, Sutinen S (2004) The use of light and electron microscopy to assess the impact of ozone on Norway spruce needles. Environ Pollut 127:441-453

Kroemer G, El-Deiry WS, Golstein P, Peter ME, Vaux D, Vandenabeele P, Zhivotovsky B, Blagosklonny MV, Malorni W, Knight RA, Piacentini M, Nagata S, Melino G (2005) Classification of cell death: recommendations of the Nomenclature Committee on Cell Death. Cell Death Differ 12:1463-1467 
Kuster TM, Arend M, Bleuler P, Gunthardt-Goerg MS, Schulin R (2013a) Water regime and growth of young oak stands subjected to air-warming and drought on two different forest soils in a model ecosystem experiment. Plant Biol. 15(Suppl 1):138-147

Kuster T, Arend M, Günthardt-Goerg M, Schulin R (2013b) Root growth of different oak provenances in two soils under drought stress and air warming conditions. Plant Soil 369:61-71

Kwon SI, Park OK (2008) Autophagy in plants. J Plant Biol 51:313-320

Leuzinger S, Zotz G, Asshoff R, Körner C (2005) Responses of deciduous forest trees to severe drought in Central Europe. Tree Physiol 25:641-650

López R, Climent J, Gil L (2010) Intraspecific variation and plasticity in growth and foliar morphology along a climate gradient in the Canary Island pine. Trees 24:343-350

Luković J, Maksimović I, Zorić L, Nagl N, Perčić M, Polić D, PutnikDelić M (2009) Histological characteristics of sugar beet leaves potentially linked to drought tolerance. Ind crop Prod 30:281-286

Marty F (1999) Plant vacuoles. Plant Cell 11:587-599

Moriyasu Y, Klionsky DJ (2004) Autophagy in plants. In: Klionsky DJ (ed) Autophagy 2003, pp 208-215

Munck L (1989) Fluorescence analysis in food. Longman Scientific and Technical, Harlow

Munné-Bosch S, Peñuelas J (2004) Drought-induced oxidative stress in strawberry tree (Arbutus unedo L.) growing in Mediterranean field conditions. Plant Sci 166:1105-1110

Noctor G, Veljovic-Jovanovic S, Driscoll S, Novitskaya L, Foyer CH (2002) Drought and oxidative load in the leaves of C3 plants: a predominant role for photorespiration? Ann Bot 89:841-850

Olmos E, Sanchez-Blanco MJ, Ferrandez T, Alarcon JJ (2007) Subcellular effects of drought stress in Rosmarinus officinalis. Plant Biol 9:77-84

Pääkkönen E, Günthardt-Goerg MS, Holopainen T (1998) Responses of leaf processes in a sensitive birch (Betula Pendula Roth) clone to ozone combined with drought. Ann Bot 82:49-59

Paoletti E, Contran N, Bernasconi P, Günthardt-Goerg MS, Vollenweider P (2009) Structural and physiological responses to ozone in Manna ash (Fraxinus ornus L.) leaves of seedlings and mature trees under controlled and ambient conditions. Sci Total Environ 407:1631-1643

Pitman WD, Holte C, Conrad BE, Bashaw EC (1983) Histological differences in moisture stressed and non-stressed kleingrass forage. Crop Sci 23:793-795

Polomski J, Kuhn N (1998) Wurzelsysteme. Paul Haupt Verlag, Bern

Rebetez M, Dobbertin M (2004) Climate change may already threaten Scots pine stands in the Swiss Alps. Theor Appl Climatol 79:1-9

Rigling A, Bigler C, Eilmann B, Feldmeyer-Christe E, Gimmi U, Ginzler C, Graf U, Mayer P, Vacchiano G, Weber P, Wohlgemuth T, Zweifel R, Dobbertin M (2013) Driving factors of a vegetation shift from Scots pine to pubescent oak in dry Alpine forests. Glob Chang Biol 19:229-240
Ristic Z, Cass DD (1991) Chloroplast structure after water shortage and high temperature in two lines of Zea mays L. that differ in drought resistance. Bot Gaz Chicago 152:186-194

Salleo S, Lo Gullo MA, Raimondo F, Nardini A (2001) Vulnerability to cavitation of leaf minor veins: any impact on leaf gas exchange? Plant Cell Envir 24:851-859

Sandermann H (1996) Ozone and plant health. Annu Rev Phytopathol 34:347-366

Saxe H, Cannell MGR, Johnsen B, Ryan MG, Vourlitis G (2001) Tree and forest functioning in response to global warming. New Phytol 149:369-399

Sheffield J, Wood E F (2008) Projected changes in drought occurrence under future global warming from Multi-model, multi-scenario, IPCC AR4 simulations. Clim Dyn 31:79-105

Slewinski ThL, Zhang C, Turgeon R (2013) Structural and functional heterogeneity in phloem loading and transport. Front Plant Sci $4: 1-11$

Soda C, Bussotti F, Grossoni P, Barnes J, Mori B, Tani C (2000) Impacts of urban levels of ozone on Pinus halepensis foliage. Environ Exp Bot 44:69-82

Tevini M, Steinmüller D (1985) Composition and function of plastoglobuli. Planta 163:91-96

Vassileva V, Demirevska K, Simova-Stoilova L, Petrova T, Tsenov N, Feller U (2012) Long-term field drought affects leaf protein pattern and chloroplast ultrastructure of winter wheat in a cultivar-specific manner. J Agron Crop Sci 198:104-117

Vollenweider P, Günthardt-Goerg MS (2006) Diagnosis of abiotic and biotic stress factors using the visible symptoms in foliage. Environ Pollut 140:562-571

Vollenweider P, Fenn ME, Menard T, Günthardt-Goerg M, Bytnerowicz A (2013) Structural injury underlying mottling in ponderosa pine needles exposed to ambient ozone concentrations in the San Bernardino Mountains near Los Angeles, California. Trees 27:895-911

Wang J, Ding Y, Wang J, Hillmer S, Miao Y, Lo SW, Wang X, Robinson DG, Jiang L (2010) EXPO, an exocyst-positive organelle, distinct from multivesicular endosomes and autophagosomes, mediates cytosol to cell wall exocytosis in Arabidopsis and tobacco cells. Plant Cell 22:4009-4030

Weis KG, Polito VS, Labavitch JM (1988) Microfluorometry of pectic materials in the dehiscence zone of almond (Prunus dulcis). J Histochem Cytochem 36:1037-1041

Wetzel S, Demmers C, Greenwood JS (1989) Spherical organelles, analogous to seed protein bodies, fluctuate seasonally inparenchymatous cells of hardwoods. Can J Bot 67:3439-3445

Yamasaki H, Sakihama Y, Ikehara N (1997) Flavonoid-peroxidase reaction as a detoxification mechanism of plant cells against $\mathrm{H}_{2} \mathrm{O}_{2}$. Plant Physiol 115:1405-1412

Zellnig G, Perktold A, Zechmann B (2010) Fine structural quantification of drought-stressed Picea abies (L.) organelles based on 3D reconstructions. Protoplasma 243:129-136 